\title{
Aktivitas Antibakteri Ekstrak Teripang Holothuria sp. Terhadap Bakteri Aeromonas hydrophila Secara In vitro
}

\author{
Roihanah S., Sukoso, Andayani S. \\ Fakultas Perikanan dan Ilmu Kelautan, Universitas Brawijaya, Malang
}

\begin{abstract}
Abstrak
Banyak penyakit yang disebabkan oleh patogenitas bakteri, sebagai contoh adalah bakteri Aeromonas hydrophila. Salah satu alternatif yang dapat dilakukan untuk mengatasi masalah tersebut adalah dengan menggunakan Teripang (Holothuria sp.) yang memiliki kandungan bioaktif sebagai bahan antibakteri. Tujuan penelitian ini adalah untuk mengetahui aktivitas antibakteri ekstrak Teripang terhadap A. hydrophila, mempelajari karakter dan struktur bakteri yang dihambat oleh ekstrak bioaktif Teripang dan mempelajari komponen bioaktif yang terkandung dalam teripang. Hasil uji cakram menunjukkan rerata zona hambat sebesar $13.188 \mathrm{~mm}$ sedangkan hasil uji MIC dan MBC menunjukkan bahwa pada dosis 0,50 mg. $\mathrm{ml}^{-1}$ mampu menghambat pertumbuhan bakteri (Bakteriostatik) dan dosis 0,55 mg.ml ${ }^{-1}$ telah dapat membunuh bakteri (Bakterisidal). Ekstrak kasar Teripang berpengaruh terhadap karakter dan struktur bakteri $A$. hydrophila yaitu dengan merusak dinding sel dan membran sel bakteri. Hasil analisis Spektofometri Infra Merah dari eksktrak Teripang dan analisis Spektrofotometri Ultra Violet dengan pelarut $n$-heksan serapan diduga mengandung senyawa Triterpenoid.
\end{abstract}

Kata kunci: Aktivitas Antibakteri, Teripang (Holothuria sp.), Aeromonas hydrophila

\section{Abstract}

Many diseases caused by bacterial pathogenicity, e.g. Aeromonas hydrophila. One alternative to overcome these problems is to use Sea Cucumbers (Holothuria sp.) which contain bioactive as antibacteria. Aims of this study were to determine the antibacterial activity of sea cucumber extracts against $\underline{A}$. hydrophila, to assess character and structure of bacterial which is inhibited by the bioactive extract of sea cucumbers and assess the contained bioactive components in sea cucumber. Disc test results showed a mean of $13.188 \mathrm{~mm}$ zone of inhibition while the MIC and MBC test results showed that at doses of $0.50 \mathrm{mg} \cdot \mathrm{ml}^{1}$ could inhibit bacterial growth (bacteriostatic) and dose of $0.55 \mathrm{mg} . \mathrm{ml}^{1}$ was bactericidal. Crude extract of sea cucumbers affect the character and structure of $\underline{A}$. hydrophila by destroying the cell walls and cell membranes. Analysis results of Infra Red and Ultra Violet Spectophotometry on sea cucumbers' extract is assumed to contain Triterpenoid compounds.

Key words: Antibacterial Activity, Sea Cucumber (

\section{PENDAHULUAN}

Mikroorganisme patogen dapat menyebabkan infeksi pada manusia, hewan, serta tanaman. Mikroorganisme dapat menimbulkan penyakit mulai dari infeksi ringan sampai pada kematian. Salah satu mikroorganisme penyebab penyakit tersebut adalah parasit, jamur, bakteri dan virus.

Penanggulangan penyakit dapat dilakukan dengan cara pencegahan dan pengobatan. Pengobatan yang biasa dilakukan adalah memberikan bahan kimia atau sejenisnya, tetapi penggunaan bahan kimia ini mempunyai dampak lingkungan yang kurang baik. Penggunaan antibiotik dalam perkembangannya sebagai

\footnotetext{
* Alamat korespondensi: S. Roihanah

Email :Roihanah@ub.ac.id

Alamat : Program Studi Pascasarjana S2 Biomedik Universitas Brawijaya
}

antibakteri ternyata menimbulkan resistensi terhadap organisme target seperti Staphylococcus aureus, Escherichia coli dan Aeromonas salmonicida [1] serta Vibrio harveyi [2].

Salah satu alternatif yang dapat dilakukan untuk mengatasi masalah tersebut adalah dengan menggunakan Teripang (Holothuria sp.) yang memiliki kandungan bioaktif sebagai bahan antibakteri [3]. Teripang mengandung bahan aktif antibakteri, antifungi (antijamur), antitumor dan antikoagulan (antipenggumpal) [4]. Penelitian telah menunjukkan bahwa selain penyembuhan luka, ekstrak Teripang mengandung senyawa antikoagulan dan antithrombosis [5], mereduksi senyawa kolesterol dan lipid, antikanker dan senyawa antitumor [6] dan senyawa antibakteri [7]. Seorang peneliti Rusia menunjukkan bahwa cucumarioside berasal dari spesies Cucumaria japonica memiliki sifat imunomodulator kuat, menunjukkan efektivitas yang tinggi terhadap $E$. 
coli, Proteus mirabilis, Neisseria meningitidis BT-2, Salmonella minnesota, Salmonella typhimurium dan Pertusis meningoencephalitis [8].

Kandungan bioaktif pada Teripang (Holothuria sp.) diharapkan dapat menjadi bakterisida baku di bidang perikanan, yang tidak menimbulkan efek resisten, bersifat alami dan ramah lingkungan. Oleh karena itu, diperlukan penelitian mengenai pemanfaatan Teripang sebagai antibakteri dan kajian yang lebih mendalam mengenai potensi bioaktif antibakteri yang ada pada Teripang yang dapat mengontrol pertumbuhan bakteri Aeromonas hydrophila.

\section{Tujuan Penelitian}

Tujuan penelitian yang dilakukan adalah untuk:

1. Mengetahui aktivitas antibakteri ekstrak Teripang terhadap Aeromonas hydrophila

2. Mempelajari karakter dan struktur bakteri yang dihambat oleh ekstrak bioaktif Teripang

3. Mempelajari komponen bioaktif yang terkandung dalam Teripang

\section{MATERI DAN METODE PENELITIAN}

\section{Materi Penelitian}

Bahan utama yang digunakan adalah Teripang (Holothuria sp.) yang diperoleh dari perairan Socah, Kabupaten Bangkalan, Jawa Timur. Biakan murni bakteri Aeromonas hydrophila diperoleh dari Laboratorium Mikrobiologi, Fakultas Kedokteran, Universitas Brawijaya, Malang.

\section{Metode Penelitian \\ Ekstraksi}

Ekstraksi dilakukan dengan menggunakan metode maserasi (perendaman) dengan lima pelarut yang berbeda dari yang bersifat polar hingga non polar, yaitu air, methanol, etanol, kloroform dan heksan. Ekstraksi dilakukan dengan merendam masing-masing $500 \mathrm{gr}$ Teripang segar dengan $500 \mathrm{ml}$ pelarut, selama 3 kali 24 jam. Selanjutnya dilakukan penyaringan dan pemekatan untuk tahap ekstraksi yang terakhir, yaitu dengan pelarut etanol dan methanol yang dipekatkan menggunakan rotary evaporator vakum. Pelarut non polar heksana dan kloroform dipekatkan dengan cara ditiup dengan gas $\mathrm{N}_{2}$, sedangkan ekstrak air dipekatkan dengan cara stirer, karena air jika menggunakan rotary evaporator tidak dapat menguap.

\section{Uji Cakram ( Metode difusi)}

Uji cakram, yaitu pengujian antimikroba dengan mengukur diameter daerah hambatan yang terjadi di sekitar kertas cakram yang sudah mengandung bahan antimikroba dan dibandingkan dengan antibiotik kanamycin. Lempeng Trypton Soya Agar (TSA) ditandai dengan nama, tanggal dan mikroorganisme yang akan diuji. Kapas lidi (cotton swab) steril dicelupkan dalam suspensi biakan uji, dengan OD: 0,1 CFU. $\mathrm{ml}^{-1}$, kemudian kapas lidi diputar pada dinding tabung (diperas) agar cairan tidak menetes dari bagian kapas tersebut. Mikroorganisme kemudian disebar pada seluruh permukaan lempeng agar dengan cara dioleskan. Untuk mendapatkan pertumbuhan yang merata, kapas lidi dioleskan secara mendatar, kemudian lempeng agar diputar $90^{\circ}$ dan dibuat olesan kedua, dengan lempeng agar diputar $45^{\circ}$ dan dibuat olesan ketiga. Lempeng agar dibiarkan mengering kurang lebih 5 menit, kemudian tempatkan kertas cakram yang sudah direndam dengan sampel yang diujikan pada permukaan lempeng agar.

Dalam 1 lempeng agar dapat digunakan 5-6 macam dosis perlakuan jarak antara kertas cakram harus cukup luas sehingga wilayah jernih tidak saling berhimpitan yang nantinya akan menyulitkan dalam proses pengukuran zona hambat. Kertas cakram ditekan dengan pinset, tidak perlu terlalu keras karena akan merusak permukaan agar. Lempeng yang sudah ditempelkan kertas cakram diinkubasi pada suhu tumbuh optimal dari bakteri patogen yang sedang diujikan. Setelah bakteri uji sudah tumbuh merata dan terlihat adanya zona jernih di permukaan agar, maka luas zona jernih dapat diukur dengan mengukur diameternya.

\section{Uji Minimum Inhibitiry Concentration (MIC) dan Minimum Bacterial Concentration (MBC)}

Tabung reaksi steril disiapkan sebanyak 24 buah dan telah diberi label konsentrasi. Dibuat konsentrasi bahan uji sesuai dengan tabel preparasi, masing-masing $1 \mathrm{ml}$. Dimasukkan $1 \mathrm{ml}$ suspensi bakteri $10^{6} \mathrm{CFU} \cdot \mathrm{ml}^{-1}$ ke dalam masingmasing tabung reaksi dan vortex hingga homogen. Semua tabung diinkubasi pada suhu $37^{\circ} \mathrm{C}$ selama 18-24 jam. Setelah 18-24 jam, diamati dan dicatat derajat kekeruhan pada semua tabung.

Selain itu dicatat nilai MIC yang merupakan konsentrasi terendah dari tabung yang tidak menunjukkan adanya kekeruhan. Untuk mengetahui nilai $\mathrm{MBC}$, dilakukan streak pada medium TSA dan diinkubasi pada suhu $37^{\circ} \mathrm{C}$ selama 24 jam. Pengamatan dilakukan dengan menghitung jumlah koloni yang tumbuh pada media agar dengan colony counter. Dari hasil perhitungan koloni tersebut dapat ditentukan MIC dan MBC dari ekstrak kasar bahan antibakteri tersebut. 


\section{Pengamatan dengan Mikroskop Elektron (SEM)}

Sebelum pengamatan mikroskopis SEM dilakukan pewarnaan gram. Sediaan dibuat di atas cover glass dan dikeringkan pada suhu kamar, jika sudah kering difiksasi dengan cara dipanaskan diatas nyala api 3-4 kali lalu dibiarkan dingin. Setelah dingin diletakan di atas rak pewarnaan. Dituangkan larutan kristal violet di atas sediaan, diamkan selama 1 menit. Sediaan dibilas dengan air, kemudian dituangi larutan Lugol dan didiamkan 1 menit dan dibilas dengan air. Sediaan dilunturkan dengan Alkohol 96\% hingga warna violet memudar dan dibilas dengan air. Kemudian sediaan dituangi larutan safranin, didiamkan 30 detik, dibilas dengan air, dikering anginkan. Setelah sediaan kering dilakukan pengamatan menggunakan mikroskop SEM.

\section{HASIL DAN PEMBAHASAN}

\section{Uji Cakram (Disk Diffusion)}

Efektivitas antibakteri ditunjukkan dengan terbentuknya zona bening di sekitar cakram. Larutan ekstrak kasar Teripang digunakan untuk pengujian aktivitas antibakteri dengan menggunakan metode difusi cakram Kirby-Bauer, yaitu pengujian antimikroba dengan mengukur diameter daerah hambatan yang terjadi di sekitar kertas cakram yang sudah mengandung bahan antimikroba sesuai dengan konsentrasi perlakuan [9].

Diameter zona hambat dari ekstrak teripang dengan pelarut air dengan rerata sebesar 6.096 $\mathrm{mm}$, methanol $6.054 \mathrm{~mm}$, etanol $6.076 \mathrm{~mm}$, cloroform $8.442 \mathrm{~mm}$ dan $n$-heksan $13.188 \mathrm{~mm}$ (Gambar 1). Pelarut $n$-heksan paling efektif dalam menghambat bakteri, karena adanya bioaktif pada Teripang berfungsi sebagai bahan antibakteri tidak bisa terlarut pada pelarut yang bersifat polar. Menurut Kimball [10], senyawa antibakteri (Triterpenoid) larut dalam pelarut non polar. Sedangkan menurut Martoyo [11], Teripang dari Famili Holothuriidae genus Holothuria, Actinopyga dan Stichopus banyak mengandung zat ekstraktif seperti senyawa Terpenoid dimana hasil hidrolisisnya mudah larut dalam pelarut organik (seperti Cloroform, eter dan $n$-heksan) dan tidak larut dalam air [12].

Zona jernih pada lapisan agar yang terbentuk karena senyawa antibakteri berdifusi ke dalam lapisan tersebut dan menghambat pertumbuhan mikroorganisme (bakteri), sedangkan lapisan agar yang ditumbuhi mikroorganisme akan tampak keruh [13]. Kanamycin sebagai antibakteri kontrol dapat menghambat seluruh bakteri uji. Kanamycin dengan konsentrasi 0,2 mg. $\mathrm{ml}^{-1}$ dengan daya penghambatan rata-rata sebesar $13,09 \mathrm{~mm}$ terlihat bahwa ekstrak teripang menunjukkan aktivitas yang hampir sama daya hambatnya dengan Kanamycin (Gambar 1).

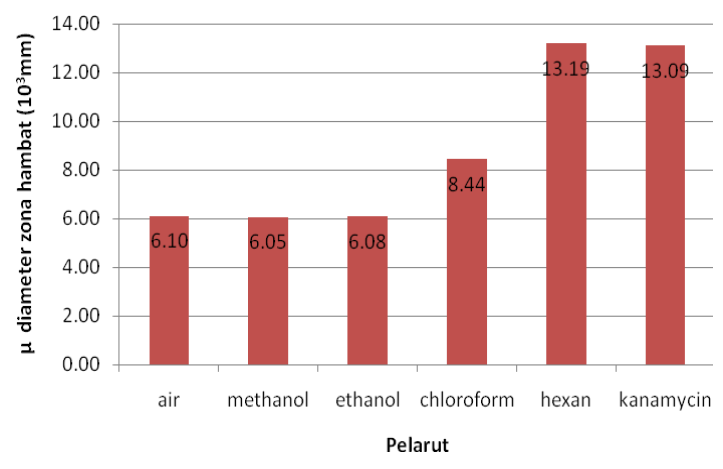

Gambar 1. Diameter daerah hambat ekstrak Teripang terhadap bakteri Aeromonas hydrophila

\section{Uji MIC dan MBC}

Pada Aeromonas hydrophila konsentrasi 0,50 $\mathrm{mg} \cdot \mathrm{ml}^{-1}$ sudah terlihat sedikit jernih, yang menandakan bahwa pertumbuhan bakteri dapat dihambat (bakterostatik) oleh ekstrak teripang dengan total bakteri $2,75.10^{1}$ CFU.plate ${ }^{-1}$ dan pada konsentrasi $0,55 \mathrm{mg} \cdot \mathrm{ml}^{-1}$ terlihat sangat jernih, menandakan bahwa pertumbuhan bakteri telah dapat dihentikan dan bakterisidal. Pelczar dan Chan [14] menyatakan bahwa antibakteri bersifat bakteriostatik atau bakterisid tergantung dari konsentrasinya. Ekstrak kasar bersifat bakterisidal karena ekstrak mampu membunuh bakteri dan bakteristatis karena ekstrak kasar hanya mampu menghambat pertumbuhan bakteri.

Senyawa antibakteri bekerja dengan cara berinteraksi dengan dinding sel bakteri sehingga mengakibatkan permeabilitas pada sel bakteri dan juga berdifusi ke dalam sel sehingga mengakibatkan pertumbuhan bakteri terhambat (bakteriostatik) atau mati (bakteriosidal) [15]. Selain itu, senyawa antibakteri juga dapat menembus membran dan berinteraksi dengan material genetik sehingga bakteri mengalami mutasi.

Golongan bakteriostatik bekerja dengan jalan menghambat sintesis protein pada ribosom bakteri melalui proses difusi pasif melalui kanal hidrofilik dan sistem transportasi aktif. Setelah antibakteri masuk ke dalam ribosom, maka akan berikatan dengan ribosom dan menghalangi masuknya kompleks tRNA-asam amino pada lokasi asam amino, sehingga bakteri tidak dapat berkembang biak [10]. 


\section{Karakter dan Struktur Bakteri yang Terhambat}

Hasil penelitian diduga ekstrak dari pelarut $n$ heksan mengandung senyawa Triterpenoid. Efek penghambatan yang terjadi pada koloni bakteri Aeromonas hydrophila disebabkan oleh kandungan senyawa aktif Teripang salah satunya adalah Triterpenoid. Secara umum golongan Triterpenoid mampu merusak membran sel, menginaktifkan enzim dan mendenaturasi protein sehingga dinding sel mengalami kerusakan karena penurunan permeabilitas. Perubahan permeabilitas membran sitoplasma memungkinkan ion-ion organik yang penting masuk ke dalam sel sehingga berakibat terhambatnya pertumbuhan bahkan hingga mematikan sel (Gambar 2).

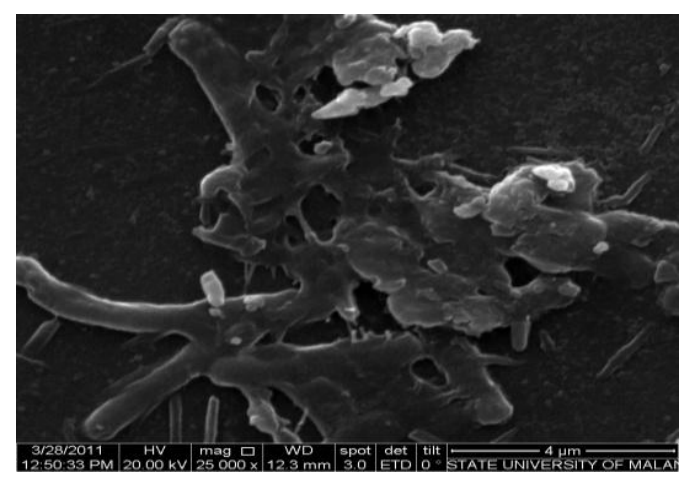

Gambar 2. Bakteri Setelah Diberi Perlakuan

\section{Hasil Pengujian Spektrofotometri Inframerah}

Hasil penelitian menunjukkan bahwa ekstrak Teripang (Holothuria sp.) dengan menggunakan alat alat FT- IR $=8400 \mathrm{~S}$ Shimadu dapat terdeteksi sebanyak 12 peak dan hasil identifikasinya dapat dilihat pada Gambar 3 berikut :

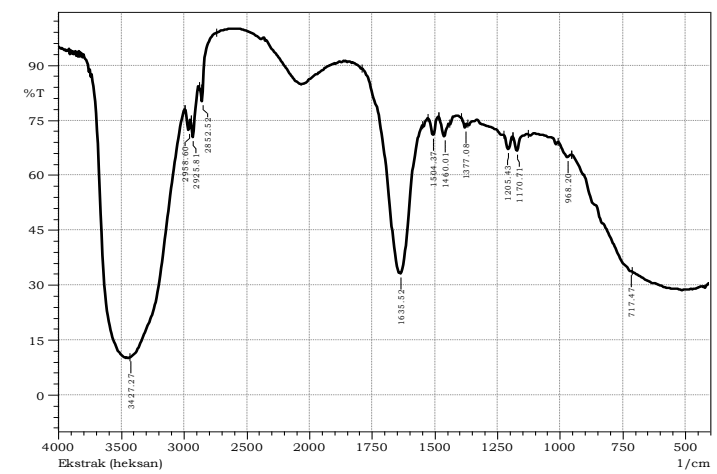

Gambar 3. Spektrum spektrofotometri Inframerah dari ekstrak n-heksan

Gambar 3 menunjukkan adanya serapan pada daerah bilangan gelombang $\left(\mathrm{cm}^{-1}\right)$ 2958,60; 2925,$81 ; 2852,52$ yang diduga serapan dari gugus
$\mathrm{CH}_{2}$. Pita serapan yang tajam pada daerah gelombang $\left(\mathrm{cm}^{-1}\right)$ 1635,52 dengan intensitas kuat mengidentikasi gugus karbonil $(C=O)$ yang pita serapannya diperkuat oleh pita serapan pada bilangan gelombang $\left(\mathrm{cm}^{-1}\right) 1205,43 ; 1170,71$. Pita serapan pada bilangan gelombang $1377,08 \mathrm{~cm}^{-1}$ menunjukkan serapan oleh gugus $\mathrm{CH}_{3}$. Pita serapan pada daerah gelombang 3427,27 $\mathrm{cm}^{-1}$ menunjukkan adanya gugus Karboksilat. Pita serapan tersebut diperkuat oleh serapan pada daerah gelombang $1635 \mathrm{~cm}^{-1}$ dengan adanya gugus $\mathrm{C}=\mathrm{O}$.

\section{Hasil Pengujian Spektrofotometri Ultra Violet}

Hasil analisis ekstrak teripang dengan pelarut $n$-heksan dengan menggunakan spektrofotometer UV-Vis memberikan tiga puncak serapan. Spektrum spektrofotometri UV-Vis dari ekstrak nheksan ditunjukkan pada Gambar 3. Munculnya serapan maksimum pada panjang gelombang 241,0 $\mathrm{nm}$ diduga diakibatkan oleh adanya transisi elektron dari $\pi-\pi^{*}$ yang disebabkan oleh adanya suatu kromofor $\mathrm{C}=\mathrm{O}$. Hal ini didukung dari hasil analisis spektrofotometri inframerah yang menunjukkan isolat mempunyai gugus pada panjang gelombang 1635,52 $\mathrm{nm}$. Serapan Ultra Violet yang landai pada panjang gelombang 352,0 $\mathrm{nm}$ dan $371,0 \mathrm{~nm}$ kemungkinan diakibatkan oleh terjadinya transisi elektron dari $n-\pi^{*}$ dari ikatan rangkap $\mathrm{C}=\mathrm{O}$ [16]. Dari hasil pengujian dengan Spektrofotometri Ultra Violet diduga ekstrak nheksan mengandung senyawa Triterpenoid.

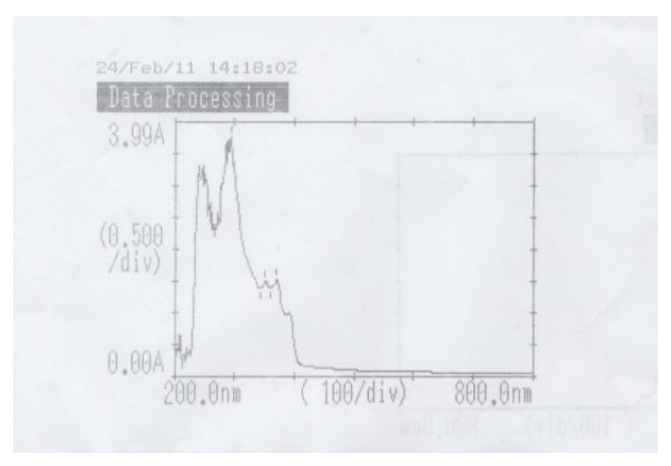

Gambar 4. Spektrum spektrofotometri UV-Vis dari ektrak n-heksan

\section{Kesimpulan}

1. Ekstrak kasar Teripang (Holothuria sp.) memiliki aktivitas antibakteri terhadap Aeromonas hydrophila

2. Ekstrak kasar Teripang berpengaruh terhadap karakter dan struktur bakteri $A$. hydrophila yaitu dengan merusak dinding sel dan membran sel bakteri 
3. Hasil analisis Spektofometri Infra Merah dan analisis Spektrofotometri Ultra Violet dengan pelarut $n$-heksan serapan dari eksktrak Teripang diduga mengandung senyawa Triterpenoid.

\section{Saran}

Disarankan untuk melakukan penelitian lebih lanjut secara In-Vivo dan melakukan purifikasi pada ekstrak kasar Teripang.

\section{DAFTAR PUSTAKA}

[1] Serrano, P. H. 2005. Responsible use of antibiotics in aquaculture. Food and Agriculture Organization of the United Nations, Rome.

[2] Karunasagar I., R. Pai, G. R. Malathi. 1994. Mass mortality of Penaeus monodon larvae due to antibiotic resistant Vibrio harveyi infection. Aquaculture, 128:203-209.

[3] Lawrence A. J.,R. Afifi, M. Ahmed, Khalifa and T. Paget. 2009. Bioactivity as an options value of Sea Cucumbers in the Egiptian Red Sea. Conserv. Biol., 24 (1): 217-225.

[4] Farrouk Abd Hamid Ghous and B.H. Ridzwan. 2007. New species isolated fron Malaysian Sea Cucumber with optimized secreted antibacterial activity, American J. of Biochem. and Biotech., 3(2): 60-65.

[5] Zancan, P. and P.A. Mourao, 2004. Venous and arterial thrombosis in rat models: dissociation of the antithrombotic effects of glycosaminoglycans. Blood Coagul. Fibrinolysis, 15: 45-54.

[6] Hatakeyama, T., N. Matsuo, K. Shiba, S. Nishinohara, N. Yamasaki, H. Sugawara and H. Aoyagi. 2002. Amino acid sequence and carbohydrate-binding analysis of the $\mathrm{N}$-acetylD-galactosamine-specific C-type lectin, CEL-I, from the Holothuroidea, Cucumaria echinata. Biosci. Biotechnol. Biochem., 66: 157-163.

[7] Afiyatullov, S. S., A. I. Kalinovsky, T. A. Kuznetsova, V. V. Isakov, M. V. Pivkin, P. S. Dmitrenok and G. B. Elyakov, 2002. New diterpene glycosides of the fungus Acremonium striatisporum isolated from a sea cucumber. J Nat. Prod., 65: 641-4.

[8] Sedov, A. M., I. B. Shepeleva, N. S. Zakharova, O. G. Sakandelidze and V. V. Sergeev. 1984. Effect of Cucumarioside (a triterpene glycoside from the Holothurian Cucumaria japonica) on thedevelopment of an immune response in mice to corpuscular pertussis vaccine. Zh. Mikrobiol. Epidemiol. Immunobiol., 9: 100-104.

[9] Bauer, A. W., W. M. M. Kirby, J. O. Sherrio, M. Turck. 1996. Antibiotic susceptibility testing by a standard single disc method. Americal Journal of clinical pathology, 45: 493-496.

[10] Kimball, John W.. 2008. Bacteria, Kimball's Biology Pages. Creative Commons Attribution 3.0 Unported (CC BY 3.0) and The Saylor Foundation.http://users.rcn.com/jkimball.ma. ultranet/BiologyPages/E/Eubacteria.html.

[11] Martoyo, J., N. Aji, dan T. Winanto, 2006, Budidaya Teripang, Cet. 6, edisi revisi, Penebar Swadaya, Jakarta.

[12] Trease, G. E., W. C. Evans. 1983. Drugs of Biological Origin. In: Pharmacognosy $12^{\text {th }}$ Ed. United Kingdom: Balliere Tindall, 309-540.

[13] Zweig, G. and J.R. Whitaker, 1971. Paper Chromatography and Electrophoresis. Academic Press. London, 397-400.

[14] Pelczar, M. J dan E.C.S. dan Chan. 1988. Dasar-Dasar Mikrobiologi Jilid 2. Alih Bahasa R.S. Hadioetomo, T. Imas, S.S. Tjitrosomo dan S.L. Angka. Penerbit Universitas Indonesia. Jakarta. 88 hal.

[15] Edberg, S. C. 1983. Tes kerentanan antimikroba. Dalam Antibiotika dan Infeksi. Alih bahasa: Chandra Sanusi. CV. EGC. Penerbit Buku Kedokteran. Jakarta. 219 hal.

[16] Sastrohamidjojo, H. 1985, Spektroskopi, Liberty, Yogyakarta. 